\title{
Constitutive expression of IGF-binding protein-3 by mammary epithelial cells alters signaling through Akt and p70S6 kinase
}

\author{
C J Grill, U Sivaprasad and W S Cohick \\ Department of Animal Sciences, Rutgers, The State University of New Jersey, 108 Foran Hall, 59 Dudley Road, New Brunswick, New Jersey \\ 08901-8520, USA \\ (Requests for offprints should be addressed to W S Cohick; Email: cohick@aesop.rutgers.edu)
}

\begin{abstract}
IGF-binding protein-3 (IGFBP-3) potentiates IGF-I action in the non-transformed mammary epithelial cell line, MAC-T, via a mechanism that is independent of its ability to bind IGF-I. The goal of the present study was to determine if IGFBP-3 might enhance IGF action by influencing intracellular signaling events downstream of the IGF receptor.

IGF-I stimulated a time-dependent activation of Akt in which phosphorylation of $\mathrm{Ser}^{473}$ was detectable by $1 \mathrm{~min}$ and maximal at $15 \mathrm{~min}$. In contrast, no activation of extracellular signal-regulated kinase (ERK)1/2 by IGF-I was observed although basal phosphorylation was readily detectable. In MAC-T cells constitutively expressing IGFBP-3 (+BP3), phosphorylation of Akt following stimulation with IGF-I was enhanced relative to mock-transfected cells (Mock). The enhancement was detectable within 1 min of IGF-I treatment and persisted for up to $10 \mathrm{~h}$. The increased phosphorylation observed by Western blotting corresponded to a 1.7-fold increase in Akt kinase activity. The enhanced Akt response was elicited by factors that activate the IGF receptor but exhibit reduced affinity for IGFBP-3, such as Long $\mathrm{R}^{3}$ IGF-I, B chain IGF-I and insulin. In contrast, [Leu ${ }^{60}$ ]IGF-I, which binds IGFBP-3 but has reduced affinity for the IGF receptor, failed to induce comparable activation, suggesting that an association between IGF-I and IGFBP-3 is not required for the effect. The enhanced Akt activation could not be mimicked by addition of exogenous IGFBP-3. Akt phosphorylation was also enhanced by transforming growth factor- $\alpha$ in $+B P 3$ cells, indicating that the effect was not specific to IGF-I. Similar to Akt, phosphorylation of p70S6 kinase $\left(\mathrm{p} 70^{\mathrm{S6K}}\right.$ ) by IGF-I was also enhanced in +BP3 cells relative to Mock cells at both $15 \mathrm{~min}$ and $10 \mathrm{~h}$. However, this was largely an effect of lower basal activation of p70 $56 \mathrm{~K}$ in $+\mathrm{BP} 3$ cells.

These data indicate that endogenous IGFBP-3 potentiates IGF action in MAC-T cells by enhancing signaling via the phosphatidylinositol 3-kinase pathway at a point that is downstream of IGF receptor activation. Further studies will delineate specific mechanisms by which IGFBP-3 may influence intracellular events that regulate growth in mammary epithelial cells.
\end{abstract}

Journal of Molecular Endocrinology (2002) 29, 153-162

\section{Introduction}

The insulin-like growth factors (IGF) regulate multiple processes including growth, differentiation and cell survival (Stewart \& Rotwein 1996). Evidence that IGF-I plays a central role in mammary development has accumulated from studies utilizing whole organ mammary cultures (Ruan et al. 1992, Plaut et al. 1993), in vivo IGF-I administration (Ruan et al. 1995) and transgenic models (Weber et al. 1998). Recently, studies with
IGF-I knockout mice have demonstrated that mammary development does not proceed in the absence of IGF-I, even if growth hormone is present (Ruan \& Kleinberg 1999). An autocrine/ paracrine mechanism of IGF action in the mammary gland is suggested by studies in mice showing that IGF-I mRNA expression is localized to the mammary epithelia of the rapidly proliferating terminal end bud as well as the surrounding stroma during postpubertal development or early pregnancy (Richert \& Wood 1999). Similarly, 
IGF-I mRNA expression is detectable in ductal epithelium and stroma of late pregnant heifers (Plath-Gabler et al. 2001). Thus, delineating the mechanism by which IGF-I regulates cellular proliferation in the mammary gland is essential to understanding both normal mammary gland development as well as abnormal growth processes involved in breast tumorigenesis and metastasis.

IGF-I regulates intracellular processes including growth by activating the IGF receptor (IGFR), a tyrosine kinase receptor that signals through both the mitogen-activated protein kinase (MAPK) and phosphatidylinositol 3-kinase (PI3K) pathways (LeRoith et al. 1995). In addition to the interaction between the IGF ligands and the IGFR, a family of high-affinity IGF-binding proteins (IGFBP) regulates IGF biological action (Ferry et al. 1999). One of these, IGFBP-3, has been shown to both potentiate as well as to inhibit cellular growth, in addition to exerting IGF-independent effects on apoptosis (Clemmons 1997, Rajah et al. 1997, Butt et al. 2000). Inhibition of IGF action by IGFBP-3 has largely been attributed to its ability to sequester IGF away from the IGFR that transduces its intracellular effects (Imai et al. 2000). However, it has also been reported that IGFBP-3 may inhibit IGF activation of the IGFR via a mechanism that is independent of a physical interaction between IGF-I and IGFBP-3 (Ricort \& Binoux 2001). In contrast, IGFBP-3 has been shown to enhance IGF-stimulated cell proliferation in both bovine mammary epithelial cells (Grill \& Cohick 2000) as well as MCF-7 breast tumor cells (Chen et al. 1994). Our laboratory has reported that the potentiating effect of IGFBP-3 on IGF-stimulated DNA synthesis is mediated by a mechanism that does not appear to involve a direct physical interaction between the IGF ligand and IGFBP-3, but does involve IGFR activation (Grill \& Cohick 2000). Therefore, the present study investigated the hypothesis that endogenous IGFBP-3 might enhance IGF action by directly influencing intracellular signaling events downstream of the IGFR.

\section{Materials and methods}

\section{Antibodies and materials}

Cell culture reagents were purchased from Life Technologies (Grand Island, NY, USA) and chemicals from Sigma (St Louis, MO, USA) unless other- wise specified. Tissue culture plasticware was from Becton Dickinson (Lincoln Park, NJ, USA). IGF-I, Long $\mathrm{R}^{3}$ IGF-I and $\left[\mathrm{Leu}^{60}\right.$ ]IGF-I were obtained from GroPep (North Adelaide, Australia). B chain IGF-I analogue was provided by Dr Margaret Cascieri (Merck, Sharp and Dohme, Rahway, NJ, USA). Recombinant glycosylated bovine IGFBP-3 was purified from Chinese hamster ovary cells as previously described (Cohick \& Clemmons 1994). Recombinant human transforming growth factor- $\alpha$ (TGF- $\alpha$ ) was from Intergen Co. (Purchase, NY, USA). Antibodies directed against phosphorylated Akt/protein kinase B (PKB) $\left(\mathrm{Ser}^{473}\right)$, phosphorylated p70S6 kinase $\left(\mathrm{p} 70^{\mathrm{S} 6 \mathrm{~K}}\right)\left(\mathrm{Thr}^{421} / \mathrm{Ser}^{424}\right)$ and total $\mathrm{p} 70^{\mathrm{S} 6 \mathrm{~K}}$ were purchased from Cell Signaling Technology (Beverly, MA, USA). Phosphospecific antibody for extracellular signal-regulated kinase (ERK)1/2 was obtained from Santa Cruz Biotechnology (Santa Cruz, CA, USA). Antibodies for total Akt/PKB and ERK1/2 were purchased from Upstate Biotechnology, Inc. (Lake Placid, NY, USA). Hygromycin was purchased from Calbiochem (La Jolla, CA, USA).

\section{Mammalian cell culture}

The MAC-T bovine mammary epithelial cell line was established from primary bovine mammary alveolar cells by immortalization with the SV40 large-T antigen (Huynh et al. 1991). The transfected MAC-T cell lines constitutively expressing bovine IGFBP-3 (+BP3) and mock-transfected control cell lines (Mock) have been previously described (Grill \& Cohick 2000). Cells were routinely cultured in Dulbecco's modified Eagle's medium supplemented with $4.5 \mathrm{~g} / 1 \mathrm{D}$-glucose, 100 $\mathrm{U} / \mathrm{ml}$ penicillin, $100 \mu \mathrm{g} / \mathrm{ml}$ streptomycin and $50 \mu \mathrm{g} / \mathrm{ml}$ gentamicin (DMEM) $+10 \%$ fetal bovine serum (FBS) at $37^{\circ} \mathrm{C}$ in a humidified atmosphere with $5 \% \mathrm{CO}_{2}$. Transfected cell lines were maintained in selection media consisting of DMEM $+10 \%$ FBS and $0 \cdot 1 \mathrm{mg} / \mathrm{ml}$ hygromycin. Prior to stimulation with growth factors, cells were incubated in serum-free phenol red-free DMEM (PRF-DMEM) supplemented with $0 \cdot 2 \%$ bovine serum albumin and $30 \mathrm{nM}$ sodium selenite for $24 \mathrm{~h}$. Media were replaced with fresh serum-free PRF-DMEM without additives \pm growth factors for the indicated times. For all experiments, hygromycin was omitted from the culture media of transfected cells. 


\section{Western immunoblotting}

Cells were lysed by the addition of lysis buffer $(1 \%$ Triton X-100, $80 \mathrm{mM} \beta$-glycerophosphate, $50 \mathrm{mM}$ HEPES, $2 \mathrm{mM}$ EDTA, $2 \mathrm{mM}$ EGTA, $10 \mathrm{mM}$ sodium fluoride, $0 \cdot 1 \%$ SDS, $1 \mathrm{mM}$ phenylmethylsulfonyl fluoride (PMSF), $2 \mathrm{mM}$ sodium orthovanadate $\left(\mathrm{Na}_{3} \mathrm{VO}_{4}\right)$, and $10 \mu \mathrm{g} / \mathrm{ml}$ leupeptin, trypsin inhibitor and aprotinin), scraped and incubated at $4{ }^{\circ} \mathrm{C}$ for $40 \mathrm{~min}$. Lysates were cleared by centrifugation at $13000 \boldsymbol{g}$ for $15 \mathrm{~min}$ at $4{ }^{\circ} \mathrm{C}$. Total protein content of the cleared lysates was determined using Bio-Rad Protein Assay (Bio-Rad, Hercules, CA, USA). Equal amounts of lysate were separated by SDS-PAGE and the resolved proteins were transferred to nitrocellulose membranes $(0 \cdot 45 \mu \mathrm{m}$; Bio-Rad) and blocked in Tris-buffered saline+ $0.05 \%$ Tween $20(\mathrm{v} / \mathrm{v})$ and $5 \%(\mathrm{w} / \mathrm{v})$ non-fat dried milk for 1 to $2 \mathrm{~h}$ at room temperature. Membranes were incubated overnight at $4{ }^{\circ} \mathrm{C}$ in the presence of specific antibodies. Immunoreactive bands were detected by incubation with horseradish peroxidase-conjugated secondary antibodies followed by ECL+ (Amersham Pharmacia, Piscataway, NJ, USA) and autoradiography. Membranes were stripped (100 mM 2-mercaptoethanol, 2\% SDS, $62.5 \mathrm{mM}$ Tris-HCl) and re-probed with antibodies directed against total protein.

\section{In vitro Akt/PKB kinase activity}

Akt $1 / \mathrm{PKB} \alpha$ kinase activity was measured using a kit from Upstate Biotechnology, Inc. according to the manufacturer's directions. Briefly, confluent cell monolayers were stimulated with $200 \mathrm{ng} / \mathrm{ml}$ IGF-I for $15 \mathrm{~min}$ and lysed in immunoprecipitation kinase buffer $(50 \mathrm{mM}$ Tris, pH 7·5, $1 \mathrm{mM}$ EDTA, $1 \mathrm{mM}$ EGTA, $0.5 \mathrm{mM} \quad \mathrm{Na}_{3} \mathrm{VO}_{4}, 0.1 \%$ (v/v) 2-mercaptoethanol, $1 \%$ Triton X-100, $50 \mathrm{mM}$ sodium fluoride, $5 \mathrm{mM}$ sodium pyrophosphate, $10 \mathrm{mM}$ sodium $\beta$-glycerophosphate, $0.1 \mathrm{mM}$ PMSF, $1 \mu \mathrm{g} / \mathrm{ml}$ leupeptin, aprotinin, pepstatin A and $1 \mu \mathrm{M}$ microcystin). Whole cell lysates were pre-cleared by centrifugation at $13000 \boldsymbol{g}$ and pre-adsorbed by incubation with protein G-agarose bead slurry. Prior to the immunoprecipitation reaction, antibody-bead immunocomplexes were formed by incubating antibodies directed against the pleckstrin homology domain of human Akt1/PKB $\alpha$ with $50 \mu$ protein G-agarose bead slurry overnight at $4{ }^{\circ} \mathrm{C}$. Aktl/PKB $\alpha$ was immunoprecipitated by incubating lysates contain- ing equal amounts of protein $(300 \mu \mathrm{g})$ with the preformed immunocomplexes for $90 \mathrm{~min}$ at $4{ }^{\circ} \mathrm{C}$. For the evaluation of in vitro $\mathrm{Aktl} / \mathrm{PKB} \alpha$ kinase activity, washed immunoprecipitates were resuspended in kinase buffer $(20 \mathrm{mM}$ MOPS, $\mathrm{pH} 7 \cdot 2$, $25 \mathrm{mM} \beta$-glycerophosphate, $5 \mathrm{mM}$ EGTA, $1 \mathrm{mM}$ $\mathrm{Na}_{3} \mathrm{VO}_{4}$ and $0 \cdot 1 \%$ 2-mercaptoethanol) and reacted with an Aktl/PKB $\alpha$-specific substrate and $\left[\gamma^{32} \mathrm{P}\right] \mathrm{ATP}$ (NEN Life Science Products, Boston, MA, USA) for $10 \mathrm{~min}$ at $30^{\circ} \mathrm{C}$ with continuous agitation. The reaction was terminated by the addition of $40 \%$ trichloroacetic acid and the reaction volume was spotted onto P81 phosphocellulose paper. Following washes in $0.75 \%$ phosphoric acid and acetone, incorporated radioactivity was measured by liquid scintillation counting.

\section{Results}

\section{IGF-I induces a time-dependent activation of Akt/PKB but not ERK1/2}

The PI3K and MAPK pathways represent two well-delineated mechanisms by which the activated IGFR transduces signals to the cell interior. To determine if IGF-I activates one or both of these pathways in MAC-T cells, we utilized phosphospecific antibodies directed against phosphorylated Akt and ERK1/2 (Fig. 1). A time-dependent activation of Akt was observed following exposure to IGF-I, indicating that IGF-I activates the PI3K pathway in this cell line. Phosphorylation of Akt was detectable following stimulation with $200 \mathrm{ng} / \mathrm{ml} \mathrm{IGF-I} \mathrm{for} \mathrm{as} \mathrm{little} \mathrm{as} 1 \mathrm{~min}$ and was sustained through $60 \mathrm{~min}$ of exposure to IGF-I with maximal phosphorylation occurring at $15 \mathrm{~min}$. In contrast, stimulation of MAC-T cells with $200 \mathrm{ng} / \mathrm{ml}$ IGF-I for up to $1 \mathrm{~h}$ failed to increase ERK1/2 phosphorylation above basal levels (Fig. 1). In addition, Western blotting with phosphospecific antibodies for two other MAPK family members, p38 and c-Jun N-terminal kinase (JNK), also failed to confirm the involvement of MAPK modules in IGF-I signaling (data not shown).

\section{Akt phosphorylation by IGF is enhanced in MAC-T cells expressing IGFBP-3}

Having established that IGF-I is likely transmitting signals via the PI3K pathway in the parental 


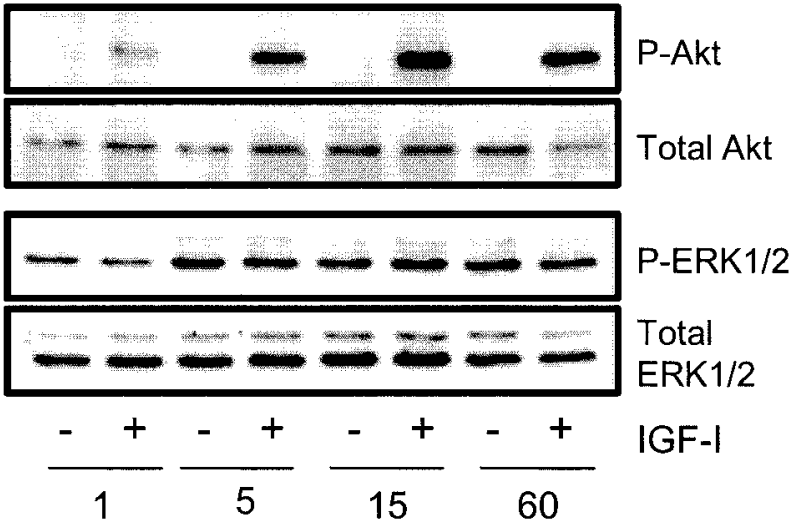

Minutes

Figure 1 IGF-I stimulation induces a time-dependent activation of Akt, but not ERK1/2 in MAC-T cells. Near-confluent cells were serum-starved for $24 \mathrm{~h}$. Media were replaced with fresh serum-free media \pm IGF-I $(200 \mathrm{ng} / \mathrm{ml})$ for the designated times. Cell lysates $(30 \mu \mathrm{g})$ were Western blotted using antibodies specific for phosphorylated (P) Akt and ERK1/2. Membranes were stripped and reprobed with antibodies that detect total Akt and ERK1/2.

MAC-T cell line, we wanted to determine if the presence of endogenous IGFBP-3 could influence phosphorylation events in this signaling cascade. IGF-I-treated cell lysates from +BP3 cells were immunoblotted with phosphospecific antibodies to Akt. Enhanced phosphorylation of Akt following stimulation with IGF-I was observed in +BP3 cells relative to Mock cells at each of the time-points examined (Fig. 2A). The enhancement was detectable within $1 \mathrm{~min}$ of IGF-I treatment, and persisted for up to $10 \mathrm{~h}$.

To ensure that this was not an inadvertent clonal effect, two additional +BP3 and two additional Mock clones were tested. As shown in Fig. 2B, Akt phosphorylation was enhanced in all three $+\mathrm{BP} 3$ clones relative to the three Mock clones following exposure to IGF-I for $15 \mathrm{~min}$. Densitometry analysis indicated that IGF-I-stimulated Akt phosphorylation was, on average, 1.8-fold greater in the + BP3 clones compared with the Mock clones at $15 \mathrm{~min}(P<0.02$ by Student's $t$-test). This effect was sustained through $10 \mathrm{~h}$ of IGF-I treatment, with a $2 \cdot 1$-fold increase in Akt phosphorylation observed $(P<0.01$ by Student's $t$-test). In addition, activation of Akt by IGF-I in wild-type parental MAC-T cells was similar to that observed in the Mock clones at both time-points. Phosphorylation of ERK1/2 in
A.

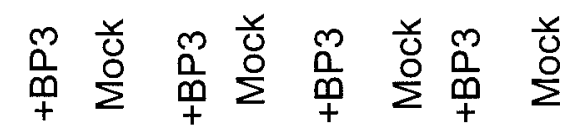

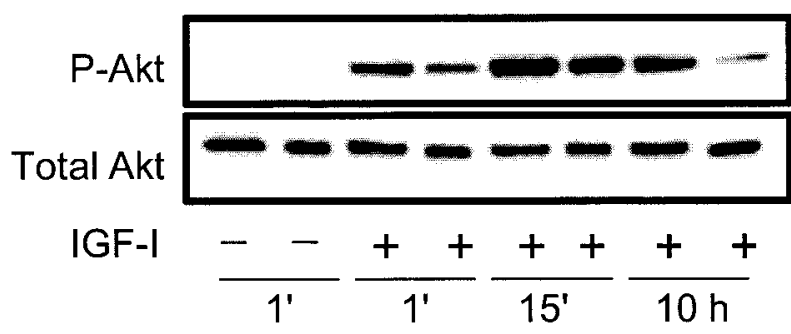

B.
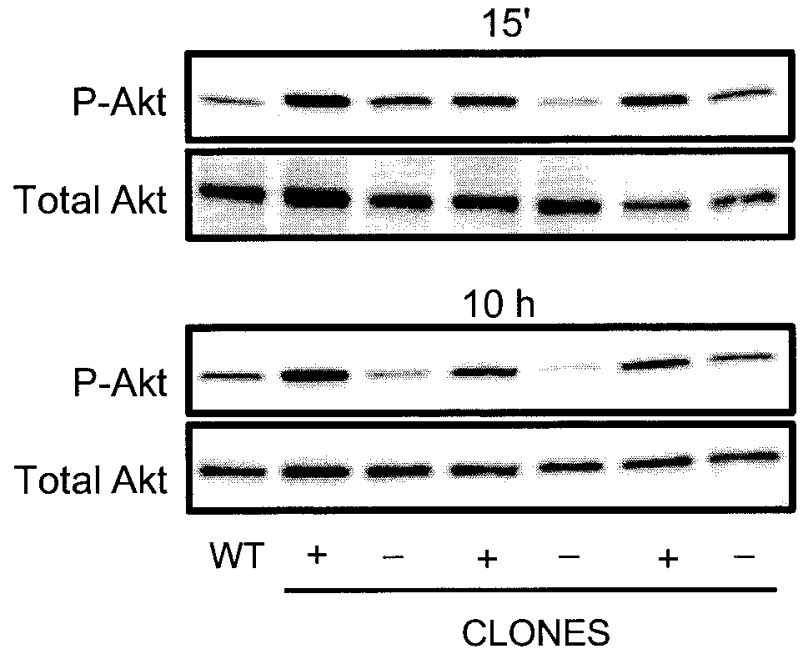

Figure 2 IGF-I-stimulated Akt phosphorylation is enhanced in MAC-T cells expressing IGFBP-3. MAC-T cells constitutively expressing IGFBP-3 (+BP3) or mock-transfected control cells (Mock) were grown to near confluence and serum-starved for $24 \mathrm{~h}$. Media were replaced with fresh serum-free media \pm IGF-I $(200 \mathrm{ng} / \mathrm{ml})$ for the indicated times. Cell lysates $(30 \mu \mathrm{g})$ were Western blotted with antibodies specific for phosphorylated Akt. Membranes were stripped and reprobed with antibodies that detect total Akt. Each panel shows a representative blot of at least four independent experiments that gave similar results. (A) Comparison of one +BP3 and one Mock clone. (B) Comparison of three individual $+\mathrm{BP} 3$ clones $(+)$, three individual Mock clones (-) and wild-type MAC-T cells (WT). Levels of phosphorylated Akt in IGF-I-treated cells were significantly greater in +BP3 versus Mock cells $(P<0.02$ at 15 min and $P<0.01$ at $10 \mathrm{~h}$ by Student's $t$-test).

cells treated with or without IGF-I was not different between $+\mathrm{BP} 3$ and Mock cells (data not shown).

To confirm that the increased phosphorylation of Akt following IGF-I stimulation corresponded to 


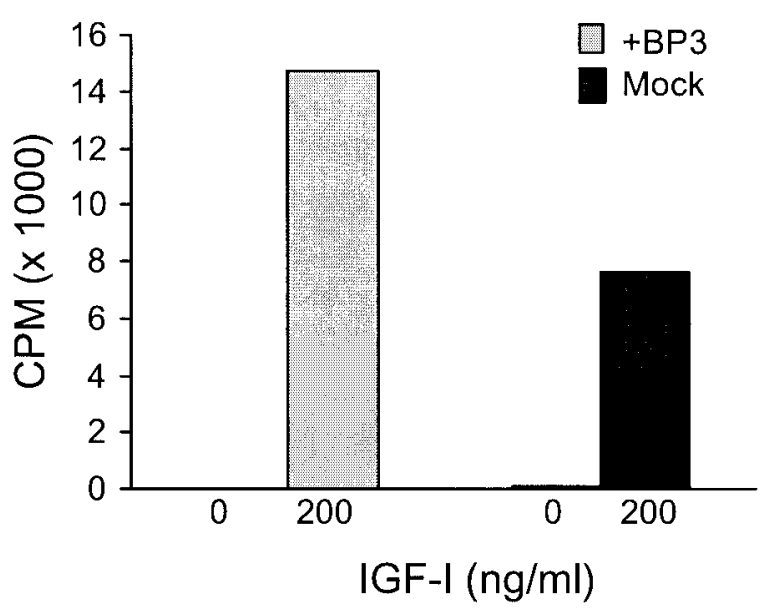

Figure 3 IGF-I-stimulated Akt kinase activity is enhanced in MAC-T cells expressing IGFBP-3. Near-confluent + BP3 or Mock cells were serum-starved for $24 \mathrm{~h}$. Fresh serum-free media \pm IGF-I $(200 \mathrm{ng} / \mathrm{ml})$ were added for $15 \mathrm{~min}$. Cell lysates were immunoprecipitated with anti-Akt antibodies and assayed for kinase activity in vitro by measuring $\left[\gamma^{32} \mathrm{P}\right]$ ATP incorporation. The results are expressed as counts per min and are representative of three separate experiments $(P<0.01$; Student's paired $t$-test).

an increase in enzymatic activity, in vitro kinase assays were performed. Exposure of + BP3 cells to IGF-I for $15 \mathrm{~min}$ increased Akt enzyme activity in each of three experiments, with increases ranging between 1.4- and 1.9-fold above the enzyme activity observed in IGF-I-stimulated Mock cells $(P<0.01$; Student's paired $t$-test $)$, confirming the results obtained by Western blotting (Fig. 3).

In order to determine if the ability of IGF-I to enhance Akt activation in +BP3 cells was independent of a physical association between the IGF ligand and IGFBP-3, IGF analogues with varying affinity for IGFBP-3 and the IGFR were tested. As shown in Fig. 4, phosphorylation of Akt was enhanced by Long $\mathrm{R}^{3} \mathrm{IGF}-\mathrm{I}$ in $+\mathrm{BP} 3$ cells relative to Mock cells. This IGF analogue activates the IGFR but exhibits reduced affinity for IGFBP-3. Similar results were observed with B-chain IGF-I (data not shown), another analogue that exhibits greatly reduced affinity for bovine IGFBP-3 but that activates the IGFR (Bayne et al. 1988). In addition, insulin at concentrations that activate the IGFR $(5 \mu \mathrm{g} / \mathrm{ml})$ produced a similar effect. In contrast, Akt activation by $\left[\mathrm{Leu}^{60}\right] \mathrm{IGF}-\mathrm{I}$, an IGF analogue with normal affinity for IGFBP-3 but reduced affinity for the IGFR, was attenuated
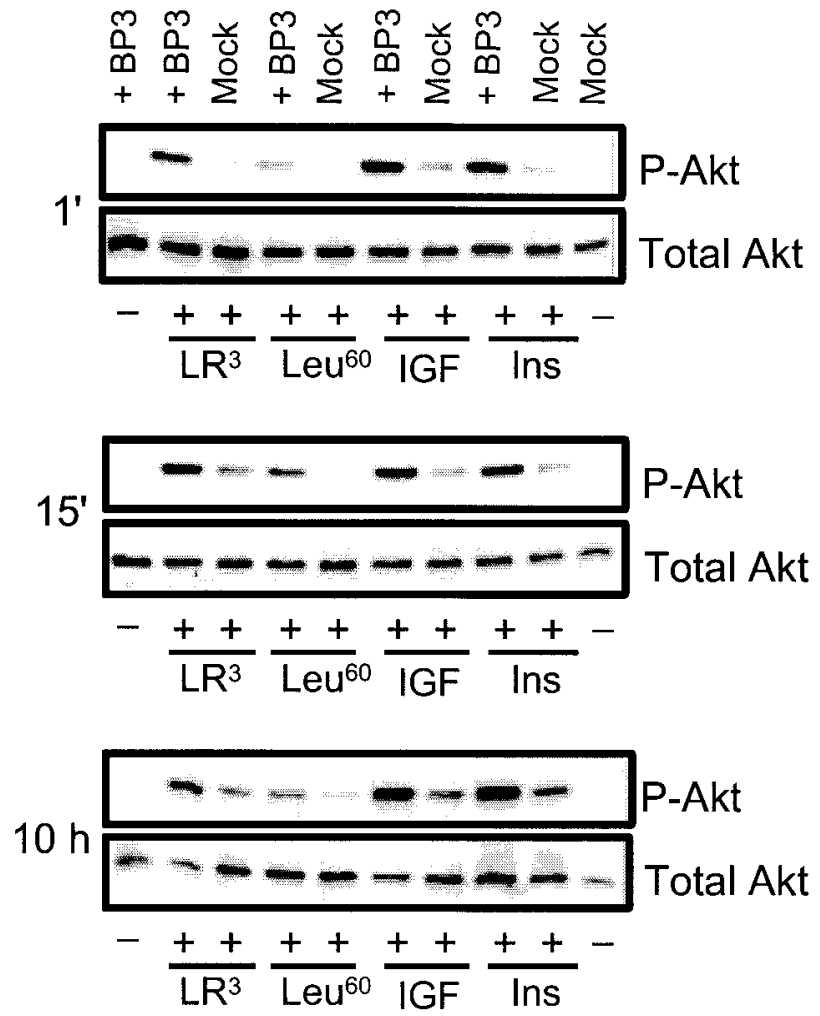

Figure 4 Enhancement of Akt phosphorylation does not require association of IGF-I with IGFBP-3.

Near-confluent +BP3 or Mock cells were serum-starved for $24 \mathrm{~h}$. Fresh serum-free media $\pm 200 \mathrm{ng} / \mathrm{ml}$ Long R $^{3}$ IGF-I $\left(\right.$ LR $\left.^{3}\right)$, [Leu ${ }^{60}$ ]IGF-I $\left(\right.$ Leu $\left.^{60}\right)$, IGF-I or $5 \mu \mathrm{g} / \mathrm{ml}$ insulin (Ins) were added for the indicated times. Cell lysates $(20 \mu \mathrm{g})$ were Western blotted with antibodies specific for phosphorylated Akt. Membranes were then stripped and reprobed with antibodies that detect total Akt. Each panel shows a representative blot of at least four independent experiments, with the exception of Leu $^{60}$ which was tested twice at all time-points.

relative to the other analogues tested in both $+\mathrm{BP} 3$ and Mock cells (Fig. 4). It is interesting that the response to $\left[\mathrm{Leu}^{60}\right] \mathrm{IGF}-\mathrm{I}$ in terms of $\mathrm{Akt}$ phosphorylation was also diminished in Mock cells relative to the Akt activation elicited by the other analogues. This suggests that, despite its markedly reduced affinity for the IGFR, [Leu $\left.{ }^{60}\right]$ IGF-I at $200 \mathrm{ng} / \mathrm{ml}$ is still sufficient to activate the receptor to some degree. This is supported by our findings that $20 \mathrm{ng} / \mathrm{ml}$ IGF-I is sufficient to maximally activate Akt (data not shown). Collectively, these data suggest that the enhanced activation of the IGFR signaling cascade observed in +BP3 cells does not require a physical association between IGF-I and IGFBP-3. 


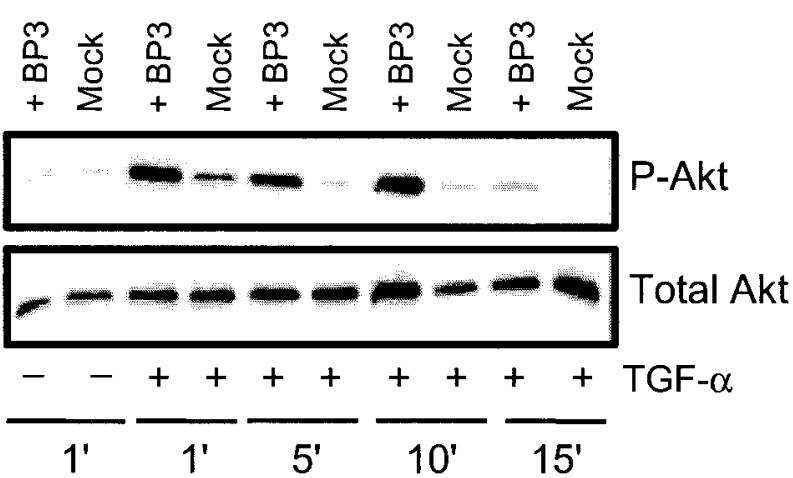

Figure 5 Akt phosphorylation is also enhanced by TGF- $\alpha$ in MAC-T cells expressing IGFBP-3. +BP3 or Mock cells were grown to near confluence and serum-starved for $24 \mathrm{~h}$. Media were replaced with fresh serum-free media \pm TGF- $\alpha(100 \mathrm{ng} / \mathrm{ml})$ for the indicated times. Cell lysates $(30 \mu \mathrm{g})$ were separated by SDS-PAGE and Western blotted with antibodies specific for phosphorylated Akt. Membranes were stripped and reprobed with antibodies that detect total Akt. Each panel shows a representative blot of two separate experiments that gave similar results.

Activation of other tyrosine kinase receptors, such as the epidermal growth factor receptor, also stimulates Akt phosphorylation via the PI3K pathway. Therefore, in order to determine if the enhanced activation of Akt in +BP3 cells was specific to the IGFR, we compared the response of + BP3 and Mock cells to TGF- $\alpha$. Similar to the IGF-I response, Akt phosphorylation was also enhanced in $+\mathrm{BP} 3$ cells by TGF- $\alpha$ relative to the Mock cells (Fig. 5). The time-course of this response was different from that observed following IGF-I treatment in that maximal activation was observed following $1 \mathrm{~min}$ of exposure to TGF- $\alpha$, and virtually gone by $15 \mathrm{~min}$. These data suggest that the enhanced activation of Akt observed in +BP3 cells is caused by an event that is downstream of IGFR activation.

\section{Exogenous IGFBP-3 does not alter activation of Akt by IGF-I}

To determine if the enhanced activation of Akt by IGF-I observed in +BP3 cells could be mimicked by exogenous IGFBP-3, Mock cells were preincubated for $24 \mathrm{~h}$ with $500 \mathrm{ng} / \mathrm{ml}$ recombinant glycosylated bovine IGFBP-3. As shown in Fig. 6, phosphorylated Akt following IGF-I stimulation was not different between Mock cells treated with

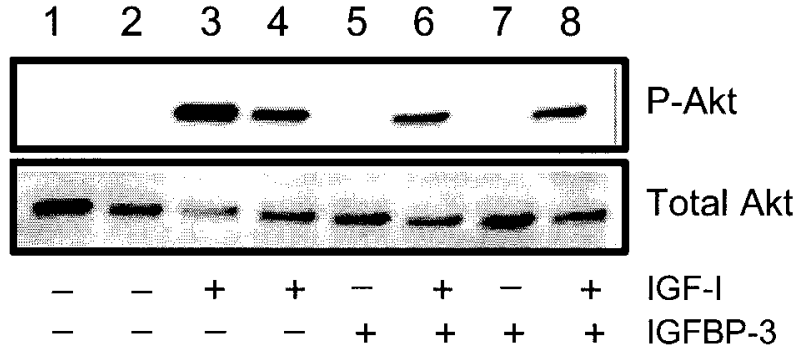

Figure 6 Exogenous IGFBP-3 does not mimic the effect of constitutive IGFBP-3 expression on IGF-I-stimulated Akt phosphorylation. Cells were grown to near confluence and serum-starved for $24 \mathrm{~h}$. Media were aspirated and replaced with fresh serum-free media \pm recombinant glycosylated bovine IGFBP-3 $(500 \mathrm{ng} / \mathrm{ml})$ for $24 \mathrm{~h}$. Media were again aspirated and replaced with fresh serum-free media \pm IGF-I $(200 \mathrm{ng} / \mathrm{ml})$ and/or IGFBP-3 $(500 \mathrm{ng} / \mathrm{ml})$ for $15 \mathrm{~min}$. Lanes represent (1) +BP3 cells without IGF-I, (2) Mock cells without IGF-I, (3) +BP3 cells+IGF-I, (4) Mock cells+IGF-I, (5 and 7) Mock cells+IGFBP-3 alone, (6 and 8) Mock cells+IGFBP-3+IGF-I. Lanes 5 and 6 represent cells treated with IGFBP-3 during the preincubation alone, while lanes 7 and 8 represent cells treated with IGFBP-3 during both the preincubation as well as the IGF-I treatment interval. Cell lysates $(20 \mu \mathrm{g})$ were separated by SDS-PAGE and immunoblotted with antibodies that recognize phosphorylated Akt. Membranes were stripped and reprobed with antibody for total Akt. Similar results were obtained in two experiments.

(lanes 6 and 8) or without (lane 4) IGFBP-3. Preincubation with IGFBP-3 did not affect Akt activation by IGF-I regardless of whether IGFBP-3 was removed prior to addition of IGF-I (lane 6) or included during IGF-I stimulation (lane 8). Addition of exogenous IGFBP-3 alone in the absence of IGF-I also failed to activate Akt (lanes 5 and 7). Lower concentrations of IGFBP-3 that more closely mimicked the levels of IGFBP-3 secreted by $+\mathrm{BP} 3$ cells $(70 \mathrm{ng} / \mathrm{ml})$ were also tested and found not to affect the ability of IGF-I to activate Akt in Mock cells (data not shown).

\section{Phosphorylation of $\mathrm{p} 70^{\mathrm{S6K}}$ by IGF-I is enhanced in MAC-T cells expressing IGFBP-3}

The ribosomal protein kinase $\mathrm{p} 70^{\mathrm{S} 6 \mathrm{~K}}$ acts as a key regulator of cell growth through control of the protein translational apparatus (Pullen \& Thomas 1997, Avruch 1998). Because p70 ${ }^{\mathrm{S} 6 \mathrm{~K}}$ is a downstream effector of Akt, we next determined whether +BP3 cells would also exhibit enhanced 

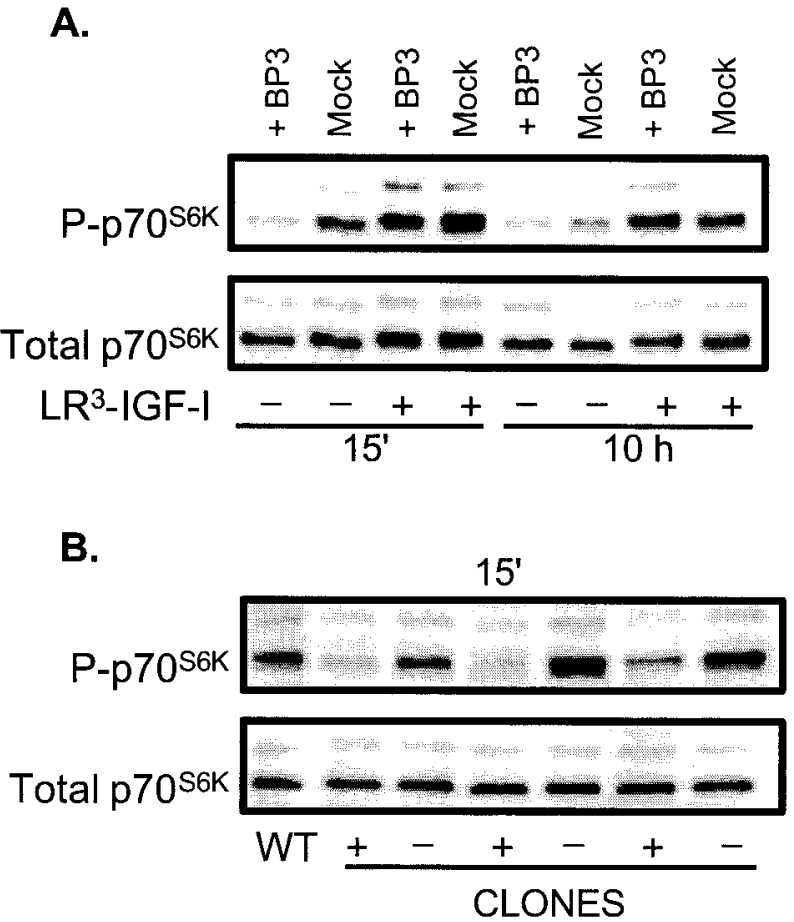

Figure 7 Activation of $p 70^{56 K}$ is enhanced in +BP3 cells due to attenuation of basal $p 70^{\text {s6K }}$ phosphorylation. Near-confluent cells were serum-starved for $24 \mathrm{~h}$. Media were replaced with fresh serum-free media for the indicated times. Cell lysates $(25 \mu \mathrm{g})$ were Western blotted with antibodies that recognize phosphorylated $\mathrm{Thr}^{421} / \mathrm{Ser}^{424}$ sites of $\mathrm{p} 70^{\mathrm{S} 6 \mathrm{~K}}$. Membranes were stripped and reprobed with antibody for total $p 70^{\text {S6K }}$ protein. $(A)$ Comparison of one +BP3 and one Mock clone treated \pm Long $\mathrm{R}^{3}$ IGF-I $(200 \mathrm{ng} / \mathrm{ml})$ for $15 \mathrm{~min}$ or $10 \mathrm{~h}$. The autoradiographs shown are representative of at least three experiments for each time-point. Activation of Akt was greater in +BP3 cells $(P<0 \cdot 01)$. (B) Comparison of basal levels of phosphorylated $\mathrm{p} 70^{\mathrm{S} 6 \mathrm{~K}}$ at $15 \mathrm{~min}$ in three individual +BP3 clones (+), three individual Mock clones (-) and wild-type (WT) MAC-T cells. Results are representative of two separate experiments $(P<0.01)$.

signaling through $\mathrm{p} 70^{\mathrm{S} 6 \mathrm{~K}}$. Western blotting was performed with an antibody specific for $\mathrm{Thr}^{421}$ / Ser ${ }^{424}$ phosphorylation sites, which detects both the p70 and p85 isoforms of $\mathrm{p} 70^{\mathrm{S} 6 \mathrm{~K}}$. As shown in Fig. 7A, Long $\mathrm{R}^{3} \mathrm{IGF}-\mathrm{I}$ stimulated phosphorylation of $\mathrm{p} 70^{\mathrm{S} 6 \mathrm{~K}}$ in both $+\mathrm{BP} 3$ and Mock cells at $15 \mathrm{~min}$ and $10 \mathrm{~h}$. Similar to Akt activation, the response to either IGF-I or Long $\mathrm{R}^{3}$ IGF-I was greater in $+\mathrm{BP} 3$ cells relative to Mock cells at both $15 \mathrm{~min}$ $(3 \cdot 9 \pm 0 \cdot 6$-fold versus $2 \cdot 0 \pm 0 \cdot 5$-fold respectively; mean \pm S.E. of four experiments; $P<0.01$ by paired Student's $t$-test $)$ and $10 \mathrm{~h}(4 \cdot 8 \pm 0 \cdot 9$-fold versus $2 \cdot 3 \pm 0 \cdot 2$-fold respectively; mean \pm s.E. of three experiments; $P<0 \cdot 01)$. The additional two $+\mathrm{BP} 3$ clones also had a greater response to IGF-I at $10 \mathrm{~h}$ relative to the additional two Mock clones (4.0-fold versus $2 \cdot 6$-fold respectively; data not shown).

Since the enhanced response appeared to be due in part to a two- to threefold lower basal phosphorylation of $\mathrm{p} 70^{\mathrm{S} 6 \mathrm{~K}}$ in the $+\mathrm{BP} 3$ cells relative to the Mock cells, we compared basal phosphorylation of $\mathrm{p} 70^{\mathrm{S} 6 \mathrm{~K}}$ at $15 \mathrm{~min}$ across the six clones directly. As shown in Fig. 7B, all three +BP3 clones had markedly lower basal phosphorylation of $\mathrm{p} 70^{\mathrm{S} 6 \mathrm{~K}}$ relative to the three Mock clones (2.9-fold difference; $P<0 \cdot 01)$. In addition, basal phosphorylation of $\mathrm{p} 70^{\mathrm{S} 6 \mathrm{~K}}$ in the parental wildtype MAC-T cells resembled that of the Mock clones.

\section{Discussion}

Intensive investigation into IGFBP-3 action has established it as a complex protein that exerts multiple effects on cellular growth and apoptosis, most likely through diverse mechanisms. The ability of IGFBP-3 to potentiate IGF-I action has been recognized for many years (DeMellow \& Baxter 1988, Conover 1992). We recently reported that MAC-T cells transfected to constitutively express IGFBP-3 were both more sensitive and responsive to IGF-I in terms of DNA synthesis. The potentiating effect of IGFBP-3 was not dependent on a physical association between IGF and IGFBP-3 since enhanced DNA synthesis was also observed with agents that activate the IGFR but do not bind IGFBP-3, such as Long $\mathrm{R}^{3} \mathrm{IGF}-\mathrm{I}$ and insulin (Grill \& Gohick 2000). The finding that IGFBP-3 could potentiate IGF action without actually binding it agrees with studies in which preincubation of bovine fibroblasts with exogenous IGFBP-3 enhanced their responsiveness to [QAYL]IGF-I, an analogue which also fails to bind IGFBP-3 (Conover 1992). However, a mechanism to explain the potentiating effect has not been definitively established to date.

Our results indicate that endogenous production of IGFBP-3 may potentiate IGF action by enhancing IGF signaling via the PI3K pathway. The serine/threonine protein kinase Akt/PKB is a downstream target of PI3K (Datta et al. 1999). In the present study, an enhanced degree of Akt phosphorylation was observed as early as $1 \mathrm{~min}$ 
and was sustained for up to $10 \mathrm{~h}$ in $+\mathrm{BP} 3$ cells. In vitro kinase assays confirmed that constitutive expression of IGFBP-3 was associated with an increase in Akt enzymatic activity relative to Mock cells.

Both Long $\mathrm{R}^{3} \mathrm{IGF}-\mathrm{I}$ and $5 \mu \mathrm{g} / \mathrm{ml}$ insulin stimulated Akt activation to a similar degree as native IGF-I in +BP3 cells. Long $\mathrm{R}^{3}$ IGF-I has been reported to bind IGFBP-3, albeit with a 45- to 60-fold lower potency than native IGF-I (Devi et al. 2001). Therefore it is difficult to definitively rule out the influence of an IGFBP-3/IGF-I interaction on the ability of IGF-I to interact with its receptor with this analogue alone. However, similar results were obtained with B chain IGF-I, an analogue in which the first 16 amino acids of IGF-I are replaced with the first 17 amino acids of the B-chain of insulin (Bayne et al. 1988). This analogue exhibits a complete loss of affinity for bovine IGFBP-3 (Clemmons et al. 1992). In addition, the finding that $5 \mu \mathrm{g} / \mathrm{ml}$ insulin, which does not bind IGFBP-3, elicits a similar response, supports the suggestion that this interaction is not essential to the enhanced signaling through Akt.

Conover et al. (2000) have recently reported that inhibition of the PI3K pathway with LY 294002 inhibited the ability of exogenous IGFBP-3 to potentiate IGF-I-stimulated aminoisobutyric acid uptake in bovine fibroblasts. Furthermore, they found that preincubation with IGFBP-3 enhanced IGF-I-stimulated Akt activation. They further postulated that preincubation with IGFBP-3 caused dephosphorylation of basal Akt, resulting in enhanced sensitivity of Akt phosphorylation to IGF-I. It is interesting that their cell culture model as well as that of the present study both represent cell lines that are not only IGF-I responsive but that synthesize IGFBP-3 in response to IGF-I (Bale \& Conover 1992, Cohick \& Turner 1998). In the present work, Akt activation was also enhanced by TGF- $\alpha$ in + BP3 cells, suggesting that the enhanced Akt activation elicited by IGF-I is mediated at a point downstream of IGFR autophosphorylation. This concurs with the findings of Conover et al. (2000) who also reported that the potentiating effect of IGFBP-3 on IGF action was not associated with enhanced phosphorylation of the IGFR or insulin receptor substrate-2 (IRS-2).

One possibility to explain the present findings is that secreted IGFBP-3 may bind to a postulated cell membrane binding site/receptor and trigger events that influence the intracellular signaling machinery. This mechanism has been proposed to explain the ability of IGFBP-3 to inhibit cellular growth and/or stimulate apoptosis independent of the IGFR system (Oh et al. 1993, Rajah et al. 1997, Baxter et al. 2000). For example, IGFBP-3 has been reported to interact with the TGF- $\beta$ receptor system to phosphorylate TGF- $\beta$ receptor I as well as the signaling molecules Smad2 and Smad3 (Fanayan et al. 2002). However, in the present study, exposure of Mock cells to exogenous IGFBP-3 alone for $24 \mathrm{~h}$ failed to stimulate Akt activation. Similarly, exogenous IGFBP-3 alone had no effect on phosphorylation of the IGFR or IRS-2 in bovine fibroblasts (Conover et al. 2000). In addition to the lack of an effect of exogenous IGFBP-3 alone, pretreatment of cells with IGFBP-3 prior to IGF-I stimulation had no effect on the ability of IGF-I to stimulate Akt phosphorylation in Mock cells. Studies by others have shown that exogenous IGFBP-3 inhibits activation of the IGFR signaling cascade by IGF-I, either by directly sequestering IGF-I away from the IGFR (Imai et al. 2000) or by a mechanism independent of IGF binding (Ricort \& Binoux 2001). The present studies examining the effect of exogenous IGFBP-3 were designed to mimic the situation in +BP3 cells and did not address whether exogenous IGFBP-3 can inhibit IGF-I activation of intracellular signaling cascades. In these experiments, the molar quantities of IGF-I exceeded those of IGFBP-3, so that all free IGF-I would not be sequestered.

Alternatively, the enhanced activation of Akt in response to IGF-I may relate to an intracellular action of IGFBP-3. IGFBP-3 contains a nuclear localization signal, and has been found in the nucleus in a number of cell lines (Jaques et al. 1997, Li et al. 1997, Schedlich et al. 1998, Wraight et al. 1998). IGFBP-3 has been shown to bind the nuclear receptor retinoid X receptor- $\alpha(\mathrm{RXR}-\alpha)$, a key regulator of gene transcription (Liu et al. 2000). The interaction between IGFBP- 3 and RXR- $\alpha$ is involved in the ability of these agents to inhibit apoptosis. IGFBP-3 contains consensus phosphorylation sites for several serine/threonine kinases including MAPK, protein kinase $\mathrm{A}$ and protein kinase $\mathrm{C}$, and phosphorylation of the secreted protein has been demonstrated (Hoeck \& Mukku 1994, Coverley \& Baxter 1997, Pattison et al. 1999). It is plausible that phosphorylation of IGFBP-3 intracellularly could modulate its ability to interact 
with components of the signaling machinery. Further studies will be necessary to determine if intracellular IGFBP-3 acts via a mechanism different from the secreted form of the protein.

The ability of PI3K to stimulate cell growth has been linked to another downstream effector, $\mathrm{p} 70^{\mathrm{S} 6 \mathrm{~K}}$. While $\mathrm{p} 70^{\mathrm{S} 6 \mathrm{~K}}$ activation was enhanced in +BP3 cells, this appeared to be related largely to an attenuation of basal $\mathrm{p} 70^{\mathrm{S} 6 \mathrm{~K}}$ phosphorylation. These findings are consistent with and may explain the lower basal $\left[{ }^{3} \mathrm{H}\right]$ thymidine incorporation yet greater IGF-stimulated DNA synthesis that is consistently observed in $+\mathrm{BP} 3$ cells relative to Mock cells (Grill \& Cohick 2000). One possibility is that IGFBP-3 may activate dephosphorylation of $\mathrm{p} 70^{\mathrm{S} 6 \mathrm{~K}}$, as has been suggested for Akt (Conover et al. 2000). However, it is interesting that the higher levels of phosphorylated Akt in IGF-Itreated cells did not appear to result in greater levels of phosphorylated $\mathrm{p} 70^{\mathrm{S} 6 \mathrm{~K}}$. The role of alternative downstream targets of Akt in mediating this effect is presently being investigated.

Results of the present study indicate that IGFBP-3 may potentially bind intracellular molecules involved in the IGFR signaling cascade or in some way modulate the ability of such molecules to activate essential components of this cascade. Confirmation of such a mechanism would expand the role of IGFBP-3 to include modulation of IGF action via effects on intracellular signaling cascades as has been suggested for its proposed IGF-independent action on apoptosis.

\section{Acknowledgements}

This work was supported by the USDA (Award 98-35026-6428 to W S C), the New Jersey Agriculture Experiment Station and the Charles and Johanna Busch Memorial Fund at Rutgers, The State University of New Jersey.

\section{References}

Avruch J 1998 Insulin signal transduction through protein kinase cascades. Molecular and Cellular Biochemistry 182 31-48.

Bale LK \& Conover CA 1992 Regulation of insulin-like growth factor binding protein-3 messenger ribonucleic acid expression by insulin-like growth factor I. Endocrinology 131 608-614.

Baxter RC, Butt AJ, Schedlich LJ \& Martin JL 2000 Antiproliferative and pro-apoptotic activities of insulin-like growth factor-binding protein-3. Growth Hormone and IGF Research $\mathbf{1 0}$ (Suppl A) $1-10$.
Bayne ML, Applebaum J, Chicchi GG, Hayes NS, Green BG \& Cascieri MA 1988 Structural analogs of human insulin-like growth factor I with reduced affinity for serum binding proteins and the Type 2 insulin-like growth factor receptor. Fournal of Biological Chemistry 263 6233-6239.

Butt AJ, Firth SM, King MA \& Baxter RC 2000 Insulin-like growth factor-binding protein-3 modulates expression of Bax and Bcl-2 and potentiates p53-independent radiation-induced apoptosis in human breast cancer cells. Fournal of Biological Chemistry 275 39174-39181.

Chen J-C, Shao ZM, Sheikh MS, Hussain A, LeRoith D, Roberts CT \& Fontana JA 1994 Insulin-like growth factor-binding protein enhancement of insulin-like growth factor-I (IGF-I)-mediated DNA synthesis and IGF-I binding in a human breast carcinoma cell line. Fournal of Cellular Physiology 158 69-78.

Clemmons DR 1997 Insulin-like growth factor binding proteins and their role in controlling IGF actions. Cytokine and Growth Factor Reviewes 8 45-62.

Clemmons DR, Dehoff ML, Busby WH, Bayne ML \& Cascieri MA 1992 Competition for binding to insulin-like growth factor (IGF) binding protein-2, 3, 4, and 5 by the IGFs and IGF analogs. Endocrinology 131 890-895.

Cohick WS \& Clemmons DR 1994 Enhanced expression of dihydrofolate reductase by bovine kidney epithelial cells results in altered cell morphology, IGF-I responsiveness, and IGF binding protein-3 expression. Fournal of Cellular Physiology 161 178-186.

Cohick WS \& Turner JD 1998 Regulation of insulin-like growth factor binding protein synthesis by a bovine mammary epithelial cell line. Fournal of Endocrinology 157 327-336.

Conover CA 1992 Potentiation of insulin-like growth factor (IGF) action by IGF-binding protein-3: studies of underlying mechanism. Endocrinology 130 3191-3199.

Conover CA, Bale LK, Durham SK \& Powell DR 2000 Insulin-like growth factor (IGF) binding protein-3 potentiation of IGF action is mediated through the phosphatidylinositol-3-kinase pathway and is associated with alteration in protein kinase $\mathrm{B} / \mathrm{AKT}$ sensitivity. Endocrinology 141 3098-3103.

Coverley JA \& Baxter RC 1997 Phosphorylation of insulin-like growth factor binding proteins. Molecular and Cellular Endocrinology $1281-5$.

Datta SR, Brunet A \& Greenberg ME 1999 Cellular survival: a play in three Akts. Genes and Development 13 2905-2927.

DeMellow JSM \& Baxter RC 1988 Growth hormone-dependent insulin-like growth factor (IGF) binding protein both inhibits and potentiates IGF-1 stimulated DNA synthesis in human skin fibroblasts. Biochemical and Biophysical Research Communications 156 199-204.

Devi GR, Graham DL, Oh Y \& Rosenfeld RG 2001 Effect of IGFBP-3 on IGF- and IGF-analogue-induced insulin-like growth factor-I receptor (IGFIR) signalling. Growth Hormone and IGF Research 11 231-239.

Fanayan S, Firth SM \& Baxter RC 2002 Signaling through the smad pathway by insulin-like growth factor-binding protein-3 in breast cancer cells. Fournal of Biological Chemistry 277 $7255-7261$

Ferry RJ Jr, Katz LE, Grimberg A, Cohen P \& Weinzimer SA 1999 Cellular actions of insulin-like growth factor binding proteins. Hormone and Metabolic Research 31 192-202.

Grill CJ \& Cohick WS 2000 Insulin-like growth factor binding protein-3 mediates IGF-I action in a bovine mammary epithelial cell line independent of an IGF interaction. Fournal of Cellular Physiology 183 273-283.

Hoeck WG \& Mukku VR 1994 Identification of the major sites of phosphorylation in IGF binding protein-3. Fournal of Cellular Biochemistry 56 262-273. 
Huynh HT, Robitaille G \& Turner JD 1991 Establishment of bovine mammary epithelial cells (MAC-T): an in vitro model for bovine lactation. Experimental Cell Research 197 191-199.

Imai Y, Moralez A, Andag U, Clarke JB, Busby WH Jr \& Clemmons DR 2000 Substitutions for hydrophobic amino acids in the N-terminal domains of IGFBP-3 and -5 markedly reduce IGF-I binding and alter their biologic actions. Fournal of Biological Chemistry 275 18188-18194.

Jaques G, Noll K, Wegmann B, Witten S, Kogan E, Radulescu RT \& Havemann K 1997 Nuclear localization of insulin-like growth factor binding protein-3 in a lung cancer cell line. Endocrinology 138 1767-1770.

LeRoith D, Werner H, Beitner-Johnson D \& Roberts CT Jr 1995 Molecular and cellular aspects of the insulin-like growth factor I receptor. Endocrine Reviews 16 143-163.

Li W, Fawcett J, Widmer HR, Fielder PJ, Rabkin R \& Keller GA 1997 Nuclear transport of insulin-like growth factor-I and insulin-like growth factor binding protein-3 in opossum kidney cells. Endocrinology 138 1763-1766.

Liu B, Lee HY, Weinzimer SA, Powell DR, Clifford JL, Kurie JM \& Cohen P 2000 Direct functional interactions between insulin-like growth factor-binding protein-3 and retinoid X receptor-alpha regulate transcriptional signaling and apoptosis. Fournal of Biological Chemistry 275 33607-33613.

Oh Y, Müller HL, Pham H \& Rosenfeld RG 1993 Demonstration of receptors for insulin-like growth factor binding protein-3 on Hs578T human breast cancer cells. Fournal of Biological Chemistry 268 26045-26048.

Pattison ST, Fanayan S \& Martin JL 1999 Insulin-like growth factor binding protein-3 is secreted as a phosphoprotein by human breast cancer cells. Molecular and Cellular Endocrinology 156 131-139.

Plath-Gabler A, Gabler C, Sinowatz F, Berisha B \& Schams D 2001 The expression of the IGF family and GH receptor in the bovine mammary gland. Fournal of Endocrinology 168 39-48.

Plaut K, Ikeda M \& Vonderhaar BK 1993 Role of growth hormone and insulin-like growth factor-I in mammary development. Endocrinology 133 1843-1848.

Pullen N \& Thomas G 1997 The modular phosphorylation and activation of p70s6k. FEBS Letters 410 78-82.

Rajah R, Valentinis B \& Cohen P 1997 Insulin-like growth factor (IGF)-binding protein-3 induces apoptosis and mediates the effects of transforming growth factor-B1 on programmed cell death through a p53-and IGF-independent mechanism. Fournal of Biological Chemistry 272 12181-12188.

Richert MM \& Wood TL 1999 The insulin-like growth factors (IGF) and IGF type I receptor during postnatal growth of the murine mammary gland: sites of messenger ribonucleic acid expression and potential functions. Endocrinology $140454-461$.

Ricort JM \& Binoux M 2001 Insulin-like growth factor (IGF) binding protein-3 inhibits type 1 IGF receptor activation independently of its IGF binding affinity. Endocrinology 142 108-113.

Ruan W \& Kleinberg DL 1999 Insulin-like growth factor I is essential for terminal end bud formation and ductal morphogenesis during mammary development. Endocrinology 140 $5075-5081$

Ruan W, Newman CB \& Kleinberg DL 1992 Intact and amino-terminally shortened forms of insulin-like growth factor I induce mammary gland differentiation and development. PNAS $\mathbf{8 9}$ 10872-10876.

Ruan W, Catanese V, Wieczorek R, Feldman M \& Kleinberg DL 1995 Estradiol enhances the stimulatory effect of insulin-like growth factor-I (IGF-I) on mammary development and growth hormone-induced IGF-I messenger ribonucleic acid. Endocrinology 136 1296-1302.

Schedlich LJ, Young TF, Firth SM \& Baxter RG 1998 Insulin-like growth factor-binding protein (IGFBP)-3 and IGFBP-5 share a common nuclear transport pathway in T47D human breast carcinoma cells. Foumal of Biological Chemistry 273 18347-18352.

Stewart CE \& Rotwein P 1996 Growth, differentiation, and survival: multiple physiological functions for insulin-like growth factors. Physiological Reviewes 76 1005-1026.

Weber MS, Boyle PL, Corl BA, Wong EA, Gwazdauskas FG \& Akers RM 1998 Expression of ovine insulin-like growth factor-1 (IGF-1) stimulates alveolar bud development in mammary glands of transgenic mice. Endocrine 8 251-259.

Wraight CJ, Liepe IJ, White PJ, Hibbs AR \& Werther GA 1998 Intranuclear localization of insulin-like growth factor binding protein-3 (IGFBP-3) during cell division in human keratinocytes. Fournal of Investigative Dermatology $111239-242$.

Received in final form 2 March 2002 Accepted 19 March 2002 